\title{
STUDIES ON THE RELATIONSHIP BETWEEN OXYGEN CONSUMPTION AND NITROGEN METABOLISM. III. IN POLYCYTHEMIA VERA
}

\author{
By ADELAIDE BARER, W. D. PAUL AND C. W. BALDRIDGE \\ (From the Department of Internal Medicine, University Hospitals, \\ State University of Iowa, Iowa City)
}

(Received for publication July 17, 1933)

In previous communications we have reported data obtained by simultaneous studies of the nitrogen metabolism and oxygen consumption in cases of pernicious anemia (1) and leukemia (2). We now wish to present similar data obtained by a study of two patients with polycythemia vera who were given phenylhydrazine.

Increased oxygen consumption has been observed in polycythemia vera by many investigators, and numerous explanations for this increased metabolism have been suggested. The subject has been briefly reviewed by Bliss (3) who summarized the explanations given by various investigators to account for the increased metabolic rate frequently observed in polycythemia vera; increased rate of cell regeneration, Abbott (4); increased rate of destruction of nuclear material, Isaacs (5); abnormal blood formation and the presence of immature cells in the circulation, Minot and Buckman (6); and deranged protein metabolism or abnormal physiologic activity of the spleen and bone marrow, suggested by, but not subscribed to, by Grafe (7). Bliss came to the conclusion that the cause of the increased heat production in polycythemia vera was unknown.

The effect of phenylhydrazine upon the rate of oxygen consumption has been touched upon by some investigators. In 1913 Eberstadt (8) gave phenylhydrazine to rabbits and observed a decrease in the oxygen consumption which he attributed to hypoplasia of the bone marrow. The work of Eberstadt was criticized by Rolly (9) who, in 1914, found that phenylhydrazine anemia in the dog was associated with an increase in oxygen consumption. For metabolic work the rabbit is not as satisfactory as the dog since it is difficult, if not impossible, to train rabbits to relax. However, neither of the above investigators give evidence that their animals were trained and only one or two metabolic tests were made during the control periods. Eberstadt's rabbits lost from one-fourth to one-third of their body weight during the experiments, a circumstance which renders most, if not all, of his conclusions invalid. Neither Eberstadt nor Rolly made daily metabolic studies, the former having made two or three deter- 
minations per month while Rolly made from six to ten observations per month.

Huffman (10) studied the effect of phenylhydrazine in patients with polycythemia vera and observed an increase in the excretion of nitrogen largely as urea. This author further states that, "Characteristic changes in the heat exchange as indicated by the basal metabolic rate, were not observed." In Huffman's Case 1 the basal metabolic rate increased from 13 per cent above normal to 29 per cent above normal, while the negative nitrogen balance increased from 1.54 gram daily to 9.24 grams daily. In the other cases the basal metabolic rate determinations were made at infrequent intervals and exact dates are not supplied, so that it is not possible to evaluate the results. It is only fair to state that studies on gaseous metabolism seem to have been more or less incidental in Huffman's investigation. Basal metabolic rates before and after treatment with phenylhydrazine, such as are recorded by Bliss, are of no special value to us, since the dates of the determinations are not given and the nitrogen metabolism was not studied simultaneously. Minot and Buckman speak of a case in which the basal metabolic rate was 40 per cent above normal at a time when the erythrocyte count was well below normal. We know of no systematic attempt to point out a relationship between the erythrocyte count and the oxygen consumption, although such relationships have been suggested in leukemia.

We have previously demonstrated that rapid regeneration of erythrocytes in pernicious anemia is associated with a decrease in total oxygen consumption (1). It would therefore seem unlikely that increased regeneration of erythrocytes in polycythemia could cause the opposite effect, as has been suggested by Abbott. The catabolism of nuclear material must require oxygen and this requirement might be enough to produce significant changes in the total oxygen consumption if such material exerts a large specific dynamic effect. However, Ringer and Rapport (11) were able to demonstrate that the metabolism of the dog remained at the basal level for six hours after the ingestion of 20 grams of either yeast or thymus nucleic acid. If it may be inferred from this observation that nucleoprotein can be catabolized by an amount of oxygen similar to, or less than, that needed for like amounts of ordinary protein, then we must conclude that Isaacs' explanation, although valid, is inadequate. Of course, it might be contended that nucleic acid could increase metabolism after an interval greater than six hours, or that it acts differently when, and if, it is liberated outside the gastro-enteric tract. The added suggestion of Minot and Buckman that immature cells in the circulation might use an excess of oxygen has been rendered invalid in the case of leukocytes (12) (13) and inadequate in the case of reticulocytes (2) by respiration studies on blood. Deranged protein metabolism, mentioned, but not subscribed to, by Grafe as a cause 
of the increased metabolism in polycythemia, may, in our opinion, be more important than its author thought.

\section{METHODS AND RESULTS}

Two patients with typical polycythemia were placed in a metabolism ward. Studies consisted of determinations of nitrogen balance, phosphorus balance, iron balance (14), basal metabolic rate (Tissot-Haldane), blood cell volume (15), hemoglobin (16) erythrocytes and leukocytes as well as observations on the differential count and reticulocyte counts. Observations which were made less frequently included determination of iron (14), phosphorus (17), bilirubin (18) and nonprotein nitrogen in the blood. The viscosity of the blood was determined by the Hess viscosimeter (19). The urine was examined for hemoglobin (20) and for urobilin (21). The amount of hemoglobin as determined by the Newcomer method was compared with the hemoglobin as calculated from the blood iron determinations. The daily intake of iron and phosphorus was calculated from Rose's tables (26). In Case 1 only part of the diet was eaten each day. Two diets were used and were alternated regularly in Case 2. Diet Number 1 contained $12.6 \mathrm{mgm}$. of iron by calculation and $13.5 \mathrm{mgm}$. by analysis. Diet Number 2 contained $12.3 \mathrm{mgm}$. by calculation and $11.2 \mathrm{mgm}$. by analysis.

The urine from Case 1 which contained hemoglobin was treated with trichloroacetic acid and iron determinations were made separately on precipitate and filtrate. The results of these determinations are shown in Table III. Determinations of albumin, globulin, cholesterol, calcium and phosphorus and phosphorus partition were made on serum or plasma, or whole blood in Case 2, by Dr. G. Stearns of the Department of Pediatrics.

Case 1. A white male, aged 65 years, had had a ruddy face and had suffered from dizziness, weakness and abdominal distress at intervals for four or five years. In August 1930 he developed a partial left hemiplegia and in March 1931 the paralysis of the left side became complete. Thrombosis of the left femoral artery necessitated amputation of the left leg in March 1932, following which the patient died.

Metabolic studies extended from October 19, 1931, to December 15, 1931. The patient's spleen was considerably enlarged and firm. Slight emphysema was the only important abnormality discovered in the thorax. From November 10 until the end of the metabolic period the patient required sedatives at night because of pain, principally in the left foot. On November 16, 1931, determinations of the basal metabolic rate were discontinued because it became necessary to administer morphine at frequent intervals. We feel that the determinations of the basal metabolic rate were unaffected by sedatives except on the last day or two. Some incontinence of urine was observed on the following days: 12, $21,22,23,24,25,26,27,28$ and 32 . The amount of urine lost was not at all great except on days 23,25 , and 26 , when small amounts were lost on three or four occasions each day. There was no loss of urine in the last three periods when the urine nitrogen was very low. 
The amount of phenylhydrazine hydrochloride administered was considerably greater than that which is generally used.

Case 2. A white male, aged 47 years, had had a ruddy complexion for 7 or 8 years. He had a condition which was diagnosed and successfully treated as peptic ulcer in 1924. In 1929 he developed osteomyelitis of the right tarsal bones. Normal function of the foot had not been completely restored at the time of our studies but there were no local signs of inflammation. He complained of distress in the splenic region.

Metabolic studies extended from November 23, 1932, to December 30, 1932. The patient's spleen was only slightly enlarged. There was no demonstrable pulmonary disease. The heart was of normal size by roentgenogram, but there was a systolic thrill and a murmur over the aortic area and an electrocardiogram

TABLE I

Data in Case 1

\begin{tabular}{|c|c|c|c|c|c|c|c|c|c|c|}
\hline Day & $\begin{array}{l}\text { Hemo- } \\
\text { globin, } \\
\text { New- } \\
\text { comer } \\
\text { method }\end{array}$ & $\begin{array}{l}\text { Hemo- } \\
\text { globin, } \\
\text { iron } \\
\text { method }\end{array}$ & $\begin{array}{c}\text { Erythro- } \\
\text { cytes }\end{array}$ & $\begin{array}{l}\text { Reticu- } \\
\text { locytes }\end{array}$ & $\begin{array}{l}\text { Leuko- } \\
\text { cytes }\end{array}$ & $\begin{array}{c}\text { Blood } \\
\text { urea } \\
\text { nitro- } \\
\text { gen }\end{array}$ & $\begin{array}{c}\text { Blood } \\
\text { uric } \\
\text { acid } \\
\text { nitro- } \\
\text { gen }\end{array}$ & $\begin{array}{l}\text { Blood } \\
\text { bili- } \\
\text { rubin }\end{array}$ & $\begin{array}{l}\text { Hemo- } \\
\text { globin in } \\
\text { urine }\end{array}$ & $\begin{array}{c}\text { Phenyl- } \\
\text { hydra- } \\
\text { zine }\end{array}$ \\
\hline $\begin{array}{l}1 \\
2 \\
3 \\
4 \\
5 \\
6\end{array}$ & $\begin{array}{c}\text { grams } \\
\text { per } \\
100 \text { cc. } \\
22.7 \\
22.3 \\
22.3 \\
22.3 \\
24.0 \\
22.3\end{array}$ & $\begin{array}{c}\text { grams } \\
\text { per } \\
100 \mathrm{cc} .\end{array}$ & $\begin{array}{c}\text { millions } \\
\text { per } \\
\text { cmm. } \\
10.2 \\
9.4 \\
9.7 \\
8.2 \\
9.2 \\
7.4\end{array}$ & $\begin{array}{c}\text { per cent } \\
0.8 \\
1.1 \\
0.6 \\
0.7 \\
0.6 \\
0.7\end{array}$ & $\begin{array}{c}\text { thous- } \\
\text { ands per } \\
\text { cmm. } \\
19.3 \\
16.9 \\
16.5 \\
19.3 \\
14.3 \\
19.0\end{array}$ & $\begin{array}{c}\text { mgm. } \\
\text { per } \\
100 \mathrm{cc} .\end{array}$ & $\begin{array}{c}\text { mgm. } \\
\text { per } \\
100 \mathrm{cc} .\end{array}$ & $\begin{array}{c}\underset{\text { per }}{\operatorname{mgm} .} \\
100 \mathrm{cc} .\end{array}$ & & grams \\
\hline $\begin{array}{r}7 \\
8 \\
9 \\
10 \\
11 \\
12 \\
13\end{array}$ & $\begin{array}{l}22.7 \\
22.3 \\
22.3 \\
22.3 \\
22.3 \\
21.0 \\
21.5\end{array}$ & $\begin{array}{l}20.3 \\
20.7 \\
20.1\end{array}$ & $\begin{array}{r}7.5 \\
7.9 \\
10.0 \\
9.2 \\
10.0 \\
7.7 \\
9.8\end{array}$ & $\begin{array}{r}0.7 \\
2.6 \\
10.5 \\
9.9 \\
10.5 \\
5.8 \\
4.2\end{array}$ & $\begin{array}{l}18.2 \\
20.5 \\
20.6 \\
17.7 \\
22.2 \\
23.1 \\
25.3\end{array}$ & 14 & 1.3 & 2 & & $\begin{array}{l}0.2 \\
0.3 \\
0.3 \\
0.3 \\
0.3 \\
0.3 \\
0.3\end{array}$ \\
\hline $\begin{array}{l}14 \\
15 \\
16\end{array}$ & $\begin{array}{l}21.0 \\
21.5 \\
20.4\end{array}$ & 20.8 & $\begin{array}{l}6.5 \\
8.6 \\
8.4\end{array}$ & $\begin{array}{l}3.5 \\
3.8 \\
5.2\end{array}$ & $\begin{array}{l}18.9 \\
21.2 \\
19.9\end{array}$ & & & & & \\
\hline $\begin{array}{l}17 \\
18 \\
19 \\
20 \\
21 \\
22\end{array}$ & $\begin{array}{l}20.1 \\
20.7 \\
18.0 \\
18.0 \\
17.8 \\
17.4\end{array}$ & $\begin{array}{l}19.3 \\
19.0 \\
18.5\end{array}$ & $\begin{array}{l}8.6 \\
8.0 \\
8.0 \\
7.1 \\
7.6 \\
7.1\end{array}$ & $\begin{array}{r}3.1 \\
8.8 \\
4.3 \\
10.3 \\
3.0 \\
3.5\end{array}$ & $\begin{array}{l}20.5 \\
25.5 \\
20.2 \\
22.2 \\
22.7 \\
38.5\end{array}$ & & & 4 & $\begin{array}{l}\text { positive } \\
\text { positive }\end{array}$ & $\begin{array}{l}0.6 \\
0.6 \\
0.4 \\
0.4 \\
0.4 \\
0.4\end{array}$ \\
\hline $\begin{array}{l}23 \\
24 \\
25 \\
26 \\
27 \\
28\end{array}$ & $\begin{array}{l}17.1 \\
15.8 \\
12.3 \\
11.5 \\
10.4 \\
10.1\end{array}$ & \begin{tabular}{r|}
15.1 \\
12.2 \\
10.1
\end{tabular} & $\begin{array}{l}6.9 \\
6.3 \\
6.4 \\
6.0 \\
4.6 \\
4.2\end{array}$ & $\begin{array}{l}5.7 \\
4.4 \\
2.0 \\
3.5 \\
5.0 \\
2.1\end{array}$ & $\begin{array}{l}45.9 \\
40.0 \\
69.7 \\
83.0 \\
83.0 \\
73.0\end{array}$ & 31 & 1.2 & $\begin{array}{r}12 \\
9 \\
13\end{array}$ & $\begin{array}{l}\text { positive } \\
\text { positive } \\
\text { positive } \\
\text { positive } \\
\text { positive } \\
\text { positive }\end{array}$ & $\begin{array}{l}0.4 \\
0.3\end{array}$ \\
\hline
\end{tabular}


TABLE I (continued)

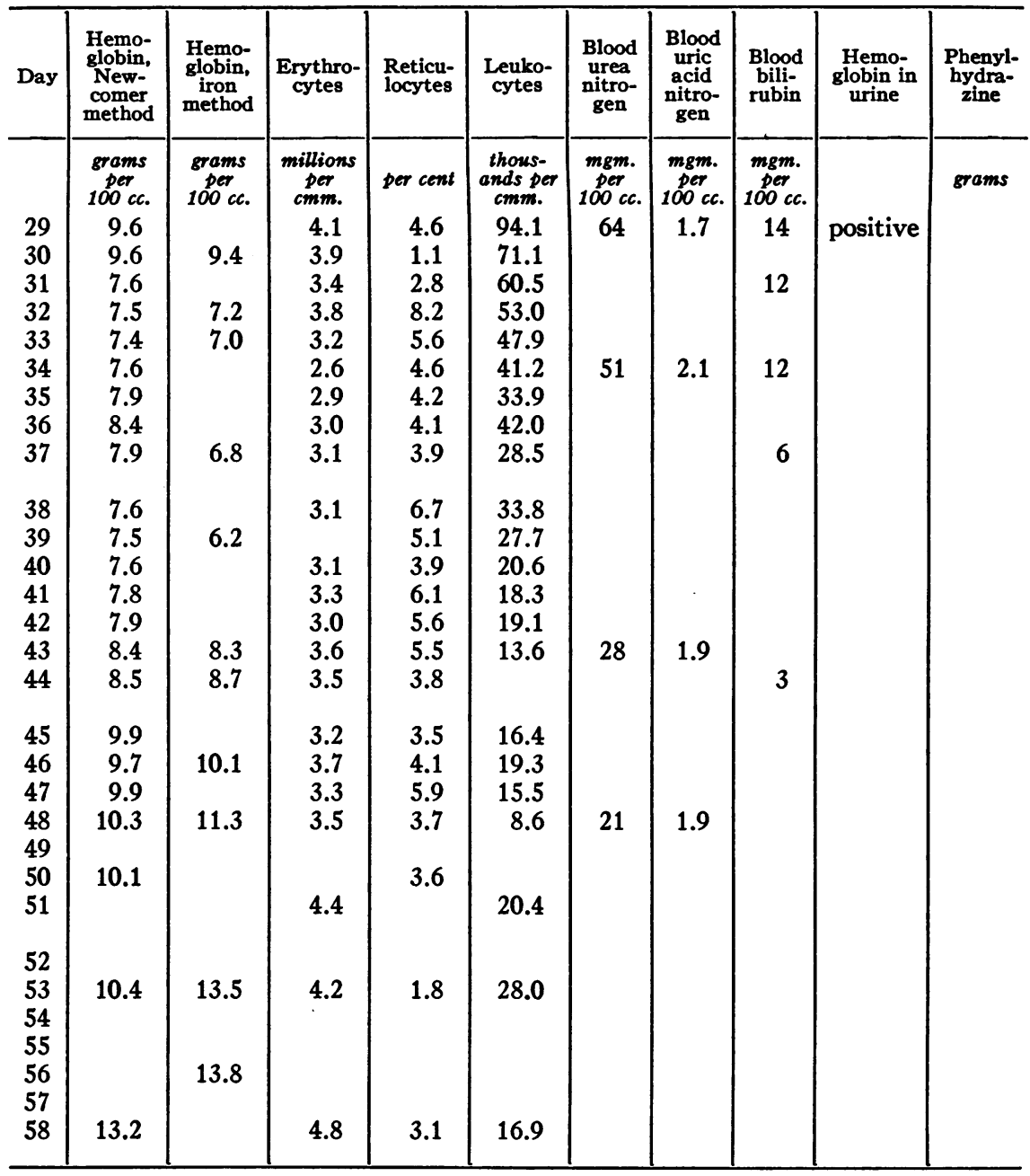

showed inverted $\mathrm{T}$ waves in all leads. There was neither cardiac pain nor congestive heart failure during the period of observation. Erythrocyte counts as high as $10,000,000$ per cu. mm. had been obtained before the patient's admission. The patient cooperated in every respect and no medication was given except acetyl phenylhydrazine.

\section{DISCUSSION}

Observation of the charts will show that in both cases there was a very definite increase in oxygen consumption coincident with the negative nitrogen balance which followed the administration of phenylhydrazine. Both blood destruction and increase in oxygen consumption made their appearance several days after phenylhydrazine was first administered. Under 
these circumstances it seems unlikely that the change in basal metabolic rate was due to a direct stimulating action of the drug upon the oxidative processes of the body cells. The data in these cases of polycythemia show a relationship between oxygen consumption and nitrogen metabolism which is similar to that previously described in pernicious anemia and in leukemia. In all these diseases the oxygen consumption is increased when there is an increase in endogenous protein catabolism.

The respiratory quotient did not change significantly during the periods of blood destruction. The body weight in Case 1 remained constant while that of Case 2 increased slightly more than one kilogram during the period of metabolic study. The mouth temperature in Case 2 remained constant throughout the period of study. There was a slight elevation of the tem-

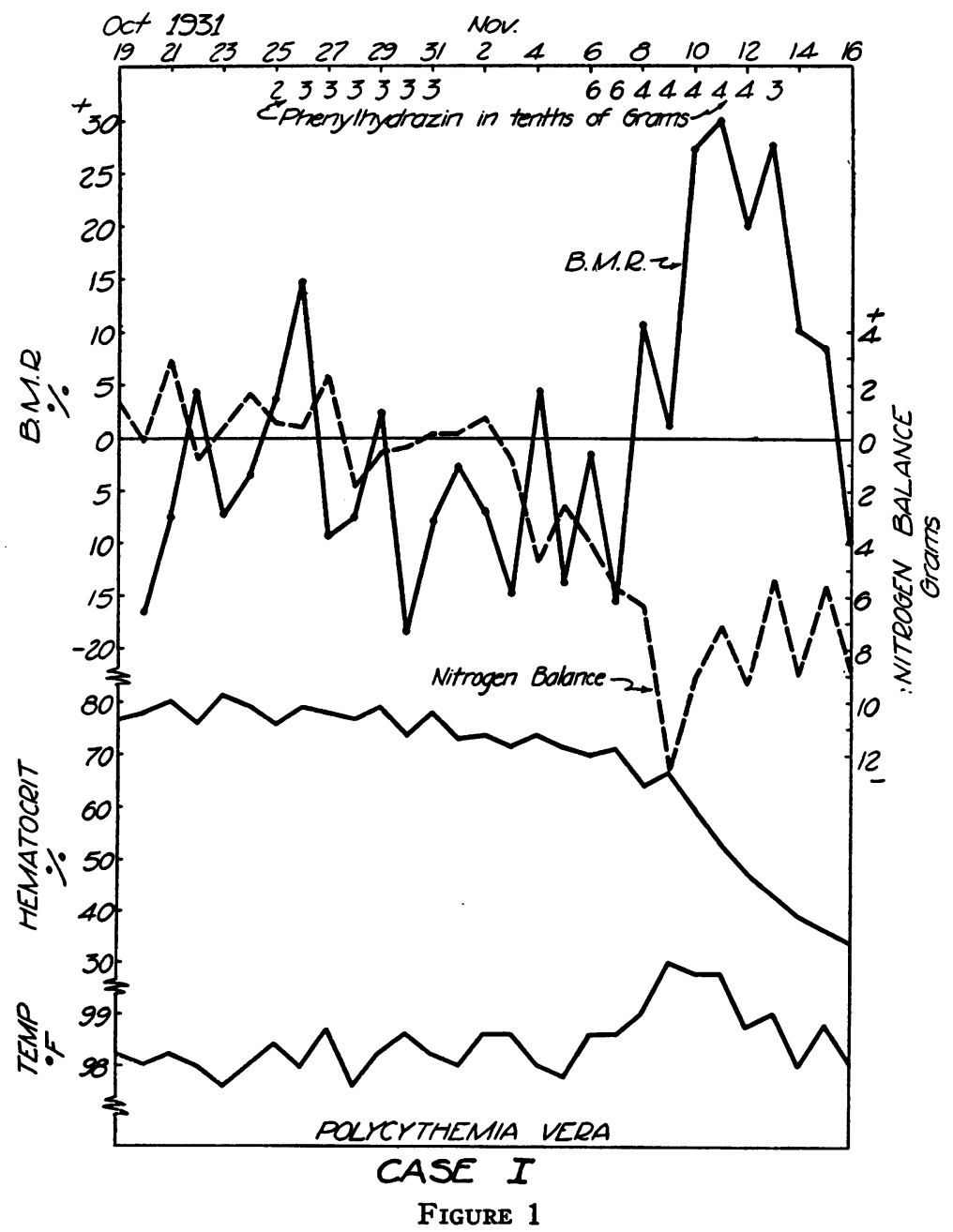


perature in Case 1 during the period of greatest nitrogen loss. This period also corresponded with the greatest increase in oxygen consumption, but the fever was insufficient to account for all of the increase in heat production. The respiratory rate varied between 12 and 20 per minute in Case 1 and between 12 and 16 per minute in Case 2. The pulse rate reached 112 per minute once in Case 1 and on four occasions it was found to be 100 per

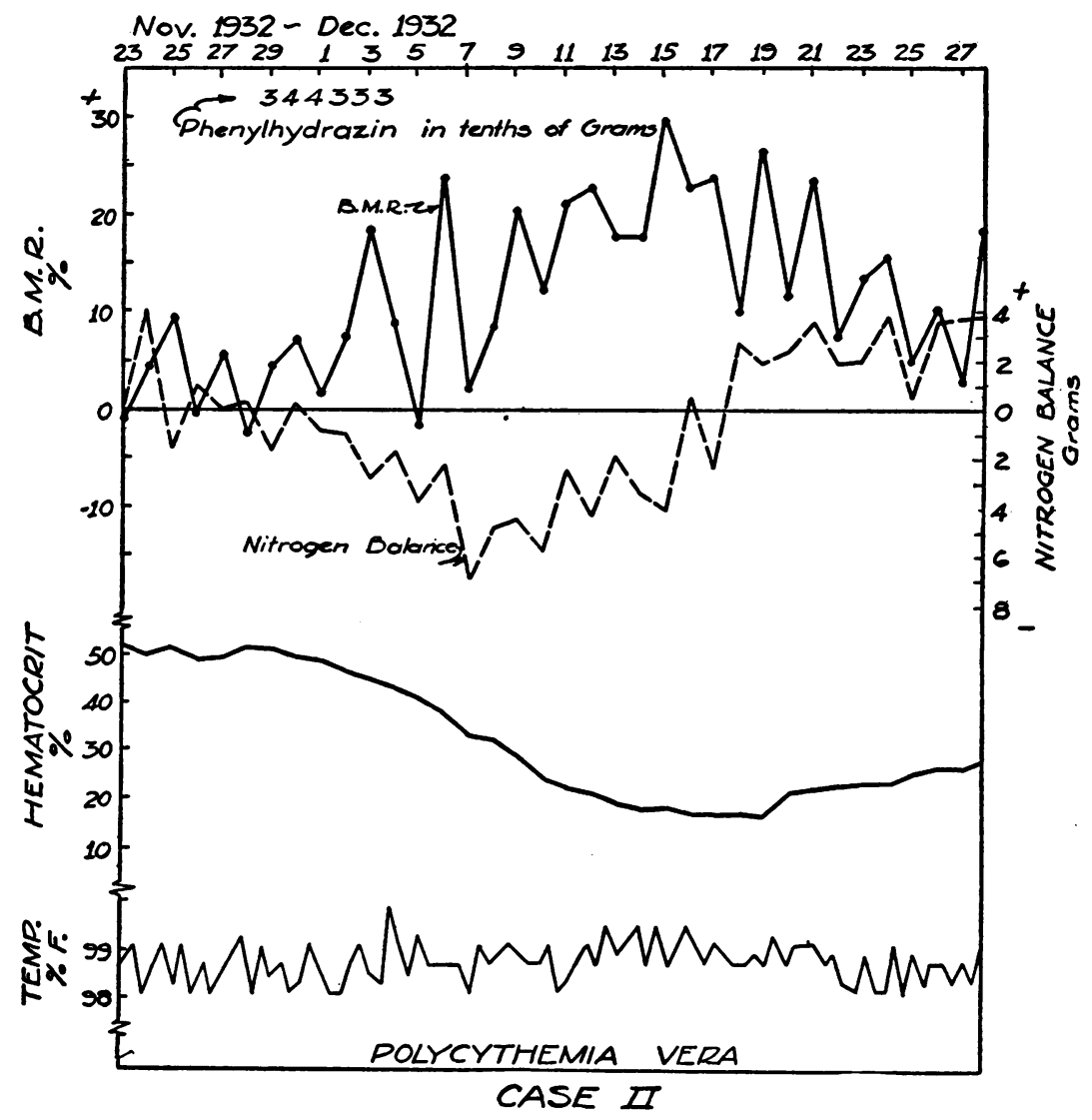

FIGURE 2

minute. In Case 2 the pulse rate did not exceed 84 per minute. The pulse and respiratory rates were determined just before and during the determination of basal metabolic rate. For a discussion of the effect of changes in the pulse and respiratory rates the reader is referred to a previous paper on leukemia (2).

The hemoglobin as determined by the Newcomer method corresponded quite well with the amount of hemoglobin as calculated from the iron content of the blood. This was true even when blood destruction was most 
marked and the blood bilirubin values were quite high. Plasma iron determinations were not made. The fact that iron was not excreted in large amounts during the period of blood destruction might indicate that the iron derived from blood destruction either did not enter the circulation or was quickly removed. During the control period in Case 1 the hemoglobin averaged 22.6 grams per $100 \mathrm{cc}$., the erythrocyte count 9.0 million per cu. $\mathrm{mm}$. and the corpuscle volume 78.5 per cent. After phenylhydrazine the hemoglobin decreased to 7.4 grams per $100 \mathrm{cc}$. and then increased to 13.2 grams at the end of the period of study. The corpuscle volume decreased to 28 per cent but was 45 per cent at the end of the period and the erythrocyte count decreased to 2.6 million per $\mathrm{cu}$. $\mathrm{mm}$. but reached 4.8 million per cu. mm. by the end of the period of observation.

In Case 2 the hemoglobin averaged 19.7 grams per $100 \mathrm{cc}$. during the control period; the corpuscle volume averaged 50.3 per cent and the erythrocyte count 6.5 million per $\mathrm{cu}$. $\mathrm{mm}$. During phenylhydrazine intoxication these values were reduced to 5.2 grams per $100 \mathrm{cc}$., 16.5 per cent and 1.6 million per cu. mm. respectively.

TABLE II

Data in Case 1

\begin{tabular}{l|c|c|c|c|c|c|c|c|c|c|c|c|}
\hline \hline Period & $\begin{array}{c}\text { Length } \\
\text { of } \\
\text { period }\end{array}$ & $\begin{array}{c}\text { Aver- } \\
\text { age } \\
\text { daily } \\
\text { caloric } \\
\text { intake }\end{array}$ & $\begin{array}{c}\text { Average } \\
\text { daily } \\
\text { urea }\end{array}$ & $\begin{array}{c}\text { Aver- } \\
\text { age } \\
\text { daily } \\
\text { uric } \\
\text { acid }\end{array}$ & $\begin{array}{c}\text { Average } \\
\text { daily } \\
\text { protein } \\
\text { in } \\
\text { urine }\end{array}$ & $\begin{array}{c}\text { Average } \\
\text { daily } \\
\text { urinary } \\
\text { nitrogen }\end{array}$ & $\begin{array}{c}\text { Aver- } \\
\text { age } \\
\text { daily } \\
\text { fecal } \\
\text { nitro- } \\
\text { gen }\end{array}$ & $\begin{array}{c}\text { Average } \\
\text { daily } \\
\text { phos- } \\
\text { phorus } \\
\text { balance* }\end{array}$ & $\begin{array}{c}\text { Aver- } \\
\text { age } \\
\text { daily } \\
\text { urinary } \\
\text { iron }\end{array}$ & $\begin{array}{c}\text { Aver- } \\
\text { age } \\
\text { daily } \\
\text { fecal } \\
\text { iron }\end{array}$ & $\begin{array}{c}\text { Average } \\
\text { daily } \\
\text { iron } \\
\text { balance* }\end{array}$ \\
\hline & days & calories & $\begin{array}{c}\text { grams of } \\
\text { nitrogen }\end{array}$ & $\begin{array}{c}\text { grams of } \\
\text { nitrogen }\end{array}$ & $\begin{array}{c}\text { grams of } \\
\text { nitrogen }\end{array}$ & grams & grams & grams & mgm. & mgm. & mgm. \\
1 & 6 & 2120 & 8.12 & 0.081 & 0.07 & 10.20 & 0.85 & +0.08 & 1.6 & 11.0 & -4.3 \\
2 & 7 & 1970 & 8.00 & 0.079 & 0.07 & 10.08 & 0.93 & +0.07 & 1.3 & 13.5 & -7.4 \\
3 & 3 & 1924 & 8.11 & 0.075 & 0.06 & 9.98 & 0.39 & +0.43 & 0.8 & 12.1 & -6.2 \\
4 & 6 & 1708 & 10.68 & 0.117 & 0.25 & 13.16 & 1.32 & +0.05 & 2.1 & 14.1 & -10.3 \\
5 & 6 & 1585 & 11.13 & 0.116 & 0.49 & 13.41 & 0.37 & +0.50 & 7.8 & 7.0 & -10.1 \\
6 & 9 & 1691 & 9.10 & 0.111 & 0.11 & 11.32 & 0.94 & -0.06 & 1.7 & 15.9 & -12.3 \\
7 & 7 & 1545 & 3.77 & 0.064 & 0.07 & 4.83 & 0.61 & +0.03 & 0.8 & 8.1 & -4.1 \\
8 & 7 & 1764 & 3.38 & 0.097 & 0.05 & 4.64 & 1.02 & +0.13 & 0.6 & 17.1 & -12.0 \\
9 & 7 & 2134 & 4.01 & 0.080 & 0.05 & 5.38 & 0.54 & +0.39 & 0.9 & 7.7 & -2.1 \\
\hline
\end{tabular}

* The amount of phosphorus and iron ingested was calculated from Rose's tables (26).

In both cases the reticulocytes increased during the period of blood destruction, in Case 1 to 10.5 per cent and in Case 2 to 22.6 per cent. The reticulocyte increase varied but persisted for many days. This observation is hard to reconcile with the impressions gained from extensive clinical use of the drug by Giffin and Allen (22), in that these authors thought that phenylhydrazine retarded blood formation. If Jackson's (23) observations that the products of leukocytic destruction stimulate leukopoiesis and if the clinical impressions that the injection of hemoglobin or whole blood 
is followed by erythropoiesis are correct, then one might have anticipated an increased rate of erythropoiesis under the conditions of these experiments.

The circulating leukocytes increased to 94,100 per cu. $\mathrm{mm}$. in Case 1 and to 20,900 per cu. $\mathrm{mm}$. in Case 2. The increase was principally in polymorphonuclear neutrophiles and on one occasion 2 per cent of myelocytes were found in the blood of Case 1 . We found no evidence which could permit us either to affirm or to deny the supposition that the leukocytosis was a response to primary destruction of leukocytes. The leukocytosis which occurred in these cases might suggest the use of phenylhydrazine in neutropenic states but its effect on the erythrocytes is so great that such a procedure would seem impractical.

The urea nitrogen of the blood increased to $64.4 \mathrm{mgm}$. per $100 \mathrm{cc}$. in Case 1 and to $17.5 \mathrm{mgm}$. per $100 \mathrm{cc}$. in Case 2 during the period of blood destruction. A slight increase was found in the uric acid nitrogen of the blood in Case 1 but the blood creatinine values were practically unchanged in both. These findings would indicate that under the conditions of this experiment urea can be formed in the liver more rapidly than it is excreted. The difference in the two patients may be one of renal efficiency. Also one might conclude that the urea forming function of the liver is not greatly damaged by phenylhydrazine, even in the excessively large doses which we used.

Blood bilirubin was much increased during blood destruction and the pigment gave a biphasic van den Bergh reaction in Case 1 . The highest values obtained were 14.0 and $5.3 \mathrm{mgm}$. of bilirubin per $100 \mathrm{cc}$. of plasma

TABLE III

The amount of urinary iron contained in precipitable protein in the presence of hemoglobinuria * (Case 1)

\begin{tabular}{c|c|c|c}
\hline \hline Day & Urinary iron & Iron in filtrate & Iron in precipitate \\
\cline { 2 - 3 } 21 & mgm. & mgm. & mgm. \\
22 & 2.10 & 1.46 & 0.50 \\
& 6.67 & 3.17 & 3.47 \\
23 & 10.17 & 7.17 & 2.59 \\
24 & 7.29 & 5.80 & 1.89 \\
25 & 10.09 & 4.63 & 5.81 \\
26 & 9.24 & 4.34 & 4.90 \\
27 & 6.38 & 4.93 & 1.19 \\
28 & 3.71 & 3.12 & 0.55 \\
\hline
\end{tabular}

* On the days in which there was hemoglobinuria, as shown by a chemical test (20) for blood, the urine was treated with trichloracetic acid, and iron determinations were made separately on the filtrate and on the precipitate. On the twenty-ninth day the amount of hemoglobin was very small and was not measured. 
in Cases 1 and 2 respectively. Here again we must assume that bilirubin can be formed more rapidly than it is excreted by the liver.

In one patient (Case 1) hemoglobin appeared in the urine and in both cases the urine was highly pigmented during the period of greatest blood destruction. A positive Schlesinger's test for urobilin in the urine was obtained on 21 of the 58 days of observation in Case 1 and in all except 2 of the 36 days in Case 2. Certainly there was no definite correlation between the amount of urobilin in the urine and the rapidity of the blood destruction. In both cases positive tests for urobilin in the urine were obtained during the control period. The total amount of pigment in the urine seemed to parallel the destruction of blood.

The excretion of phosphorus after phenylhydrazine did not correspond closely to the nitrogen excretion as was the case in our patients with leukemia who were treated with roentgen ray (2). Both patients remained approximately in phosphorus equilibrium. Similar findings have been recorded by Bassett, Killip and McCann (24) who have discussed a possible explanation for the failure of these patients to lose phosphorus during phenylhydrazine intoxication.

Bassett, Killip and McCann as well as Reznikoff (25) have demonstrated that very little if any of the hemoglobin iron liberated by phenylhydrazine intoxication is lost from the body. In this regard our findings are in accord with those of the investigators previously mentioned. Whereas Bassett and his co-workers found a slight retention of iron during the period of greatest blood destruction, the patient reported by Reznikoff as well as both of ours suffered slight losses of iron. Although the amount of iron in the feces of our Case 1 varied from one period to another, we do not feel that our findings lend support to the supposition of Bassett and his co-workers that food iron is better absorbed during rapid blood destruction than at other times. In fact, the small amount of iron which our Case 2 lost during blood destruction was accounted for principally by an increase of iron in the feces. The urinary iron was increased in Case 1 during the period of greatest blood destruction (Table II). During control periods the average excretions of iron in the urine were 1.6 and $1.3 \mathrm{mgm}$. daily, while the urinary iron values exclusive of hemoglobin iron averaged $5.1 \mathrm{mgm}$. daily during the period of greatest blood destruction. During the immediately subsequent periods the urinary iron diminished as is shown by average daily excretions of $1.7,0.8,0.6$, and $0.9 \mathrm{mgm}$., respectively, for four periods of about 7 days each. In Case 2 the average amount of urinary iron was very close to $1.0 \mathrm{mgm}$. daily. No significant variation in this amount occurred during the periods of blood destruction and subsequent erythropoiesis.

The excretion of creatinine in the urine was not materially changed during the period of blood destruction in either patient. The same was true of the excretion of uric acid and ammonia. There was a slight in- 
TABLE IV

Data in Case 2

\begin{tabular}{|c|c|c|c|c|c|c|c|c|c|}
\hline Day & $\begin{array}{c}\text { Hemo- } \\
\text { globin, } \\
\text { Newcomer } \\
\text { method }\end{array}$ & $\begin{array}{l}\text { Hemo- } \\
\text { globin, } \\
\text { iron } \\
\text { method }\end{array}$ & $\begin{array}{c}\text { Erythro- } \\
\text { cytes }\end{array}$ & $\begin{array}{l}\text { Reticu- } \\
\text { locytes }\end{array}$ & $\begin{array}{l}\text { Leuko- } \\
\text { cytes }\end{array}$ & $\begin{array}{c}\text { Blood } \\
\text { urea } \\
\text { nitro- } \\
\text { gen }\end{array}$ & $\begin{array}{c}\text { Blood } \\
\text { uric } \\
\text { acid } \\
\text { nitrogen }\end{array}$ & $\begin{array}{c}\text { Blood } \\
\text { bilirubin }\end{array}$ & $\begin{array}{l}\text { Phenyl- } \\
\text { hydrazine }\end{array}$ \\
\hline & $\begin{array}{l}\text { grams per } \\
100 \text { cc. }\end{array}$ & $\begin{array}{l}\text { grams per } \\
100 \text { cc. }\end{array}$ & $\begin{array}{l}\text { millions } \\
\text { per cmm. }\end{array}$ & per cent & $\left|\begin{array}{l}\text { thousands } \\
\text { per cmm. }\end{array}\right|$ & $\begin{array}{c}\text { mgm. per } \\
100 \text { cc. }\end{array}$ & $\begin{array}{l}\text { mgm. per } \\
100 \text { cc. }\end{array}$ & $\begin{array}{l}\text { mgm. per } \\
100 \text { cc. }\end{array}$ & grams \\
\hline 1 & 18.9 & 19.6 & & 2.5 & & 14 & 1.7 & 0.2 & \\
\hline 2 & 19.2 & & 6.7 & 2.3 & 10.7 & & & & \\
\hline 3 & 19.5 & & & 2.0 & & 14 & 1.8 & 0.3 & \\
\hline 4 & 20.7 & & 6.1 & 3.0 & 10.8 & & & & \\
\hline 5 & 19.8 & 19.8 & & 2.6 & & & & & \\
\hline 6 & 20.1 & & 6.8 & 2.8 & 9.4 & & & & \\
\hline 7 & 18.9 & 18.9 & & 2.5 & & & & & 0.3 \\
\hline 8 & 18.0 & & 6.1 & 3.2 & 10.2 & 14 & 1.7 & 0.1 & 0.4 \\
\hline 9 & 17.4 & 17.2 & & 1.3 & & 11 & 1.4 & 0.4 & 0.4 \\
\hline 10 & 15.3 & & 5.4 & 1.8 & 11.5 & & & & 0.3 \\
\hline 11 & 14.7 & 15.0 & 5.1 & 2.0 & 8.6 & 11 & 1.4 & 1.3 & 0.3 \\
\hline 12 & 14.9 & & 5.3 & 2.5 & 10.6 & & & & 0.3 \\
\hline 13 & 14.2 & 14.1 & & 1.7 & & & & & \\
\hline 14 & 12.9 & & 4.2 & 2.4 & 9.7 & & & & \\
\hline 15 & 13.1 & 12.7 & & 3.6 & & 15 & 1.1 & 3.3 & \\
\hline 16 & 10.4 & & 3.6 & 2.9 & 15.2 & & & & \\
\hline 17 & 9.8 & 10.1 & & 2.8 & & & & & \\
\hline 18 & 8.9 & & 3.2 & 2.5 & 11.7 & & & & \\
\hline 19 & 8.7 & 8.8 & & 2.6 & & & & & \\
\hline 20 & 7.2 & & 2.5 & 3.0 & 15.4 & & & & \\
\hline 21 & 7.3 & 6.8 & & 3.9 & & & & & \\
\hline 22 & 6.3 & & 2.3 & 6.5 & 19.4 & 18 & 1.3 & 5.3 & \\
\hline 23 & 5.7 & 5.8 & & 22.6 & & & & & \\
\hline 24 & 5.8 & & 2.1 & 15.3 & 14.6 & & & & \\
\hline 25 & 5.5 & 5.4 & & 13.7 & & & & & \\
\hline 26 & 5.4 & & 1.7 & 9.6 & 20.9 & & & & \\
\hline 27 & 5.3 & 5.6 & 1.6 & 15.2 & 9.4 & & & & \\
\hline 28 & 6.4 & & 2.3 & 19.9 & 11.0 & & & & \\
\hline 29 & 6.8 & 5.8 & 2.2 & 18.2 & 9.5 & & & & \\
\hline 30 & 7.2 & & 2.2 & 17.8 & 7.7 & & & & \\
\hline 31 & 7.2 & 7.7 & & 11.2 & & & & & \\
\hline 32 & 7.5 & & 2.2 & 8.2 & 5.9 & & & & \\
\hline 33 & 7.7 & 8.3 & & 7.9 & & & & & \\
\hline 34 & 7.8 & & 3.0 & 6.4 & 9.8 & & & & \\
\hline 35 & 7.9 & 8.4 & & 5.1 & & & & & \\
\hline 36 & 8.3 & & 3.0 & 8.2 & 6.9 & 11 & 1.4 & 0.2 & \\
\hline
\end{tabular}

crease in proteinuria in both patients during the period of blood destruction. Most of the increase in nitrogen excretion was accounted for by a very definite increase in urea in the urine. This observation was also made by Huffman (10). The marked increase in urea excretion without a corresponding increase in the excretion of uric acid indicates that in these 
experiments it was not catabolism of nucleoprotein which caused the increase in oxygen consumption. In leukemia (2) an increase in endogenous nitrogen catabolism was induced by irradiation of the splenic area. This procedure caused a moderate increase in uric acid excretion along with a considerable excess excretion of urea, and was accompanied by an increase in oxygen consumption. However, these observations do not prove that the catabolism of nucleoprotein is unimportant in causing an increase of basal metabolism such as that which is frequently observed in untreated cases of polycythemia vera.

TABLE V

Data in Case 2

\begin{tabular}{|c|c|c|c|c|c|c|c|c|c|c|c|}
\hline Period & $\begin{array}{l}\text { Length } \\
\text { of } \\
\text { period }\end{array}$ & $\begin{array}{c}\text { Aver- } \\
\text { age } \\
\text { daily } \\
\text { caloric } \\
\text { intake }\end{array}$ & $\begin{array}{c}\text { Average } \\
\text { daily } \\
\text { urea }\end{array}$ & $\begin{array}{l}\text { Aver- } \\
\text { age } \\
\text { daily } \\
\text { uric } \\
\text { acid }\end{array}$ & $\begin{array}{c}\text { Aver- } \\
\text { age } \\
\text { daily } \\
\text { protein } \\
\text { in urine }\end{array}$ & $\begin{array}{c}\text { Aver- } \\
\text { age } \\
\text { daily } \\
\text { urinary } \\
\text { nitrogen }\end{array}$ & $\begin{array}{c}\text { Aver- } \\
\text { age } \\
\text { daily } \\
\text { fecal } \\
\text { nitrogen }\end{array}$ & $\begin{array}{c}\text { Average } \\
\text { daily } \\
\text { phos- } \\
\text { phorus } \\
\text { balance }\end{array}$ & $\begin{array}{c}\text { Aver- } \\
\text { age } \\
\text { daily } \\
\text { urinary } \\
\text { iron }\end{array}$ & $\begin{array}{c}\text { Aver- } \\
\text { age } \\
\text { daily } \\
\text { fecal } \\
\text { iron }\end{array}$ & $\begin{array}{l}\text { Average } \\
\text { daily } \\
\text { iron } \\
\text { bal- } \\
\text { ance }\end{array}$ \\
\hline & days & $\begin{array}{l}\text { calo- } \\
\text { ries }\end{array}$ & $\begin{array}{l}\text { grams of } \\
\text { nitrogen }\end{array}$ & $\underset{\text { nitrogen }}{\text { grams of }}$ & $\begin{array}{l}\text { grams of } \\
\text { nitrogen }\end{array}$ & grams & grams & grams & mgm. & mgm. & mgm. \\
\hline 1 & 6 & 2916 & 10.16 & 0.145 & 0.12 & 12.24 & 1.09 & +0.27 & 0.90 & 7.67 & +4.1 \\
\hline 2 & 6 & 2765 & 11.44 & 0.156 & 0.12 & 13.56 & 1.16 & +0.20 & 1.06 & 10.77 & -0.4 \\
\hline 3 & 6 & 2822 & 14.52 & 0.142 & 0.14 & 17.16 & 1.25 & +0.61 & 0.96 & 19.67 & -8.9 \\
\hline 4 & 6 & 2702 & 12.33 & 0.158 & 0.14 & 14.44 & 1.30 & +0.77 & 0.85 & 16.00 & -5.6 \\
\hline 5 & 6 & 2726 & 7.97 & 0.174 & 0.15 & 10.32 & 1.12 & +0.35 & 1.00 & 15.67 & -6.3 \\
\hline 6 & 6 & 2686 & 6.96 & 0.212 & 0.18 & 9.30 & 1.00 & +0.24 & 1.03 & 11.67 & -2.4 \\
\hline
\end{tabular}

There was a very profound decrease in the relative viscosity of the blood of both patients. In Case 1 the readings were 15.3 and 2.2, before and after phenylhydrazine, and in Case 2, 10.7 and 3.1 respectively. Readings of about 4.5 were obtained when normal blood was subjected to the same technique. Such a decrease in viscosity must result in a diminution of the cardiac work of such patients. Judging by our calculations in a previous paper (2) we would not expect this change in cardiac work to cause a significant change in the total metabolism of the patient.

By measurement of the diameter of the erythrocytes and by calculation of the volume indices, it appears that slightly larger erythrocytes are found following the hemolysis caused by phenylhydrazine. In neither case did the blood smear resemble that of pernicious anemia and the color index did not show a definite increase.

In Case 2 the blood calcium remained within normal limits as did the inorganic phosphorus. The total phosphorus of whole blood diminished as the erythrocyte count decreased but the lipid phosphorus fraction remained nearly constant. The serum albumin decreased from 4.9 per cent in the control period to 3.2 per cent after phenylhydrazine. The serum globulin increased from 2.1 per cent during the control period to 3.6 per cent after phenylhydrazine. 


\section{SUMMARY}

Phenylhydrazine administered to two patients with polycythemia vera effected a number of metabolic changes.

1. A temporary negative nitrogen balance developed which was referable to a marked increase in excretion of urea and a slight increase in proteinuria together with a decrease in the nitrogen intake.

2. The variations of total oxygen consumption observed were parallel to the changes occurring in the endogenous nitrogen catabolism.

3 . The relatively huge quantity of iron liberated by destruction of erythrocytes was nearly all retained in the body.

4. The rapid destruction of blood by phenylhydrazine was attended by an increase in circulating reticulocytes.

5. Both urea and bilirubin were formed more rapidly than they were excreted.

6. The patients remained approximately in phosphorus balance.

7. Case 2 showed a moderate leukocytosis and Case 1 a very marked leukocytic response to phenylhydrazine.

8. Urobilin appeared in the urine of both patients at frequent intervals. This pigment did not appear to be much more concentrated in the urine during periods of blood destruction than at other times. Hemoglobin appeared in the urine of Case 1. Most of the urinary pigment during blood destruction was unidentified.

9. The blood viscosity decreased greatly during the period of blood destruction.

10. In Case 2 the albumin-globulin ratio dropped from 2.3 to 0.9 during the period of blood destruction.

11. The average size of the erythrocytes increased but slightly during the period when hemoglobin ingredients were probably most plentiful.

12. The doses of phenylhydrazine which were employed are too large for routine clinical use.

\section{BIBLIOGRAPHY}

1. Baldridge, C. W., and Barer, A., Studies on the relationship between oxygen consumption and nitrogen metabolism. I. In pernicious anemia, J. Clin. Invest., 1931, 10, 529.

2. Baldridge, C. W., and Barer, A., Relationship between oxygen consumption and nitrogen metabolism. II. In leukemia, Arch. Int. Med., 1933, 51, 589.

3. Bliss, T. L., Basal metabolism in polycythemia vera, Ann. Int. Med., 1929, 2, 1155.

4. Abbott, Maude E., The determination of basal metabolism by the "respiratory valve and spirometer method" of indirect calorimetry, with an observation on a case of polycythemia with splenomegaly, Canad. M. A. J., 1918, 8, 491.

5. Isaacs, R., Pathologic physiology of polycythemia vera, Arch. Int. Med., 1923, 31, 289. 
6. Minot, G. R., and Buckman, T. E., Erythremia (Polycythemia rubra vera), Am. J. M. Sc., 1923, 166, 469.

7. Grafe, E., Die Pathologische Physiologie des Gesamtsoff- und Kraftwechsels bei der Ernährung des Menschen, Ergebn. d. Physiol., 1923, 21, Pt. 2, 461.

8. Eberstadt, F., Uber den Einfluss chronischer experimenteller Anämieen auf den respiratorischen Gaswechsel, Arch. f. exper. Path. u. Pharmakol., 1913, 71, 329.

9. Rolly, F., Über den respiratorischen Gaswechsel bei chronisch anämischen Zuständen, Deutsches Arch. f. klin. Med., 1914, 114, 605.

10. Huffman, L. D., Metabolic studies in the treatment of polycythemia vera with phenylhydrazine, Arch. Int. Med., 1927, 39, 656.

11. Ringer, M., and Rapport, D., The influence of the metabolism of the nucleic acids on heat production, J. Biol. Chem., 1923, 58, 475.

12. Glover, E. C., Daland, G. A., and Schmitz, H. L., The metabolism of normal and leukemic leukocytes, Arch. Int. Med., 1930, 46, 46.

13. Barron, E. S. G., and Harrop, G. A., Jr., Studies on blood cell metabolism. V. The metabolism of leukocytes, J. Biol. Chem., 1929, 84, 89.

14. Reis, F., and Chakmakjian, H. H., Colorimetric method for quantitative determination of iron in blood in the form of dispersed Prussian blue, J. Biol. Chem., 1931, 92, 59.

15. Van Allen, C. M., An hematocrit method, J. Lab. and Clin. Med., 1925, 10, 1027.

16. Newcomer, H. S., A new optical instrument for the determination of hemoglobin, J. Biol. Chem., 1923, 55, 569.

17. Fiske, C. H., and Subbarow, Y.: The colorimetric determination of phosphorus, J. Biol. Chem., 1925, 66, 375.

18. Gibson, R. B., The Determination of Plasma Bilirubin; A Modified Van den Bergh Test. (To be published.)

19. Bircher, M. E., Clinical diagnosis by the aid of viscosimetry of the blood and the serum with special reference to the viscosimeter of W. R. Hess, J. Lab. and Clin. Med., 1921, 7, 134.

20. Phenolphthalein test. Practical Physiological Chemistry, Hawk, P. B., and Bergeim, O. Blakiston and Co., Philadelphia, 1931, 10th ed., p. 368.

21. Schlesinger's test. Clinical Diagnosis by Laboratory Methods, Todd, J. C., and Sanford, A. H., Saunders, Philadelphia, 1927, 6th ed., p. 159.

22. Giffin, H. Z., and Allen, E. V., The control and complete remission of polycythemia vera following the prolonged administration of phenylhydrazine hydrochlorid, Am. J. M. Sc., 1933, 185, 1.

23. Jackson, H., Jr., Parker, F., Jr., Rinehart, J. F., and Taylor, F. H. L., The studies of diseases of the lymphoid and myeloid tissues. VI. The treatment of malignant neutropenia with pentose nucleotides, J. A. M. A., $1931,97,1436$.

24. Bassett, S. H., Killip, T., and McCann, Wm. S., Mineral exchanges of man. III. Mineral metabolism during treatment of a case of polycythemia vera, J. Clin. Invest., 1931, 10, 771.

25. Reznikoff, P., Iron metabolism studies, J. Clin. Invest. (Proc.), 1932, 11, 807.

26. Rose, Mary S., A Laboratory Handbook for Dietetics, Macmillan Co., New York, 1929, 3rd ed. 